\title{
Ethical exegesis and ethical body in the philosophy of E. Levinas
}

\section{Poleshchuk}

European Humanities University (Vilnius), Tauro g. 12, Vilnius 01114, Lithuania

For citation: Poleshchuk I. Ethical exegesis and ethical body in the philosophy of E. Levinas. Vestnik of Saint Petersburg University. Philosophy and Conflict Studies, 2018, vol. 34, issue 3, pp. 356-368. https:// doi.org/10.21638/11701/spbu17.2018.304

In this paper, I attempt to show that Levinas's thesis "ethics as first philosophy" implies a complex approach to philosophical discourse as well as to language. I hope to demonstrate that, according to Levinas, the pattern of reading and debating produced by the long tradition of Western philosophical thinking has to be revised. This implies several conceptual steps which could be described as ethical exegesis and ethical body. The ethical exegesis manifests a practice of listening to and being for the other interlocutor, that primarily directed to the embodied subject in all its vivacity of life. Adhering to phenomenological tradition I explore Levinas's account of language - the saying and the said, to show that the core of the linguistic structure is sensibility and embodied proximity. My main argument is that Levinas does not only revise the work of language in philosophical discourse, but he also finds another approach to dialogue, response, and listening. In other words, objectifying language becomes posterior and is subordinated to ethical exegesis that is described as an encounter with the embodied other. I also draw attention to specific structures of sensibility and proximity which are necessary components of the ethical body. One of the important theses to follow up is that Levinas's continual refinement of the concept of exegesis is necessary for retracing an approach to the transcendence in a dialogue of two interlocutors.

Keywords: Levinas, ethics, exegesis, embodiment, proximity, sensibility, ethical body, language, saying, said.

\section{Introduction}

Being the birthplace and home for all reasoning and deliberate thinking, philosophy gave rise to ethics, aesthetics, and science. Born within the realm of Western philosophy the 'science' gradually became a core stone that has been ruling and dominating almost any discourse over the last two and a half millennia. From the first glance, Levinas indeed reads the history of philosophy as a source of concepts and inspirations for modern science. However, he approaches the history of philosophy in a very ambiguous way. Constantly not only addressing the heritage of history of philosophy in his texts but also building up his ethics on it, he does not have in mind a very halloed and highly respected discipline with impressive compendiums of texts, rather he discloses it as a great potentiality for modern sciences and a possibility for integrated technologies. However, it also seems that Levinas reads the history of philosophy in a very critical way as being a rigid construction seeking out the truth and being obsessed by the eternal appearance of "the

(C) Санкт-Петербургский государственный университет, 2018 
real things", and where quaint and bizarre phenomena were constantly dismissed and outcast. In short, following Levinas's reading the history of philosophy also promotes science as the first philosophy. Another critical view elucidates Levinas's interpretation of the history of philosophy seen as a history of ontology where the primacy of ontology tends to encompass the diversity of all phenomena within comprehension and to reduce plurality to the unity.

Now, by keeping these perspectives in mind, I would like to turn to Totality and Infinity, where Levinas elaborates his famous thesis - "ethics is first philosophy". The exposition of this thesis does not touch upon the philosophical content or essence of ethics, Levinas's project is to turn attention to ethics as one, which is occupying the first and the privileged position within a philosophical kingdom. Levinas begins by saying that one should question the status and the hierarchy: the long run of the history of Western philosophy is a constant struggle for the truth, attempting to bring into presence the triumph of science. The ethics, then, being restricted to imperative, has occupied the second or even third place after science. Being knowledge of science and truth, the philosophical reflection was always the first practice, and only after which ethics egresses. However, to say that "ethics is first philosophy" is something radically new in the history of philosophical thought is not completely fair. As has been shown in his works, Levinas indeed addresses Kant and is in accord with him in many places. Kant affirms the primacy of ethics - "the primacy of practical reason", however, his ethics was always unfolding itself as the ethics of rationality in the sense that it discusses a morality conforming to and subordinated to the standards of science.

Moving from Kantian realm Levinas's ambiguous projects proposes to conceive ethics ethically. He attacks the hegemony exercised by the circling play of truth and knowledge and by widely accepted rules of an epistemologically oriented philosophy, i.e. philosophy contributing to fields of science. The shift Levinas makes is articulated around the statement that ethics is not just grounded in the power of reason but on the surplus of morality. The simplicity of this idea has a hidden difficulty which does not directly concern philosophical practice and method but the acts of morality. Otherwise than Being Levinas's cutting edge comment says that "No one is good voluntarily" [1, p. 11]. Indeed, the care and responsibility for the other before oneself interrupts the vitality of one's own life, energies, and enjoyment. To some extent the care for the other also leads to a restriction of freedom of the self, it restrains speech, possibly limits resources and breaks through widely accepted standards of our knowledge. Thus, Levinas's thesis 'to see ethics as first philosophy' is no longer to perform philosophical questioning in the first place, rather it would lead to the questioning of philosophical discourse itself. In many cases of philosophical discussion, the motivational standpoint would be to grasp the nature and the meaning of science. This, of course, would lead to the bigger discussion with a focus on Levinas's profound account of science, truth, and technology initiated by the whole tradition of the history of western philosophy. However, this is not a topic of this paper, and, to summarise a general context of this discussion, I shall add that for Levinas the relationship between philosophy, search for truth and ethics should be reformulated: one must approach and understand the ethics of the history of philosophy and philosophical practice, and the ethics that constitute science.

To conclude a brief introduction, I accentuate that Levinas understands the search for the truth certainly not just as a function of pure mind conversing silently, transpar- 
ently, and simultaneously with itself, neither the truth is extracted from the causality of the material world. Rather, it is inextricably linked to the human realm and human interests. Therefore, Levinas's approach to philosophy starts with ethics, and precisely with ethics of communication which is the sensibility and responsiveness of one singular embodied human being. The face of the other breaks the sophisticated quest of the history of philosophy, and it breaks its historical and linguistic context. Thus, the first world of any philosophical discussion is not spoken or written but, as Levinas would put it, it is a signification of sensibility. It is an embodied word prior to all words but which would also be the cause of all other words and speech. Prior to anything said, including the proposition of scientific knowledge with all its methodology and formulas, at the very possibility of meaningfulness we are faced by what is said by one person to another, in other words, before the formation of any knowledge there is embodied sensibility of listening.

There are many questions and ideas that I would like to address in this paper. I believe that Levinas's thesis "ethics as first philosophy" implies a more complex approach which could be grasped in terms of 'ethical exegesis'. I will show that ethical exegesis derives from Levinas's account of language and discloses sensibility and proximity in the form of the saying. My main argument is that Levinas does not only revise the work of language but he also finds another approach to dialogue, response and listening by introducing two means or two 'effective' solutions - ethical exegesis and ethical body, or, the ethical sensibility that can shed light on the philosophical practice ${ }^{1}$.

\section{Ethical exegesis, language, and proximity}

Before I give an extended analysis of the role of ethical exegesis I shall elucidate the theme of language in Levinas's ethics. Outside any discursive formulation, the relation with the other person opens itself in the language which is revealed through the notion of the said and the saying. The issue of language becomes more fully orchestrated in Otherwise than Being or Beyond the Essence. I will briefly describe the key features of Levinas's understanding of language.

The structure of any linguistic act is regulated by two intertwined concepts: the said and the saying. In Levinas's interpretation, the said (le dit) belongs to an objectifying sphere. It can also be described as originality of the I experience, i.e., the ability to state 'I am this'. The saying (le dire) is recalled to tear the totality of the subject's being as it is expressed in the said. It demolishes the limits of language as a settled and logically organized structure.

To represent alterity and to catch it in the experience of consciousness means to find a certain meaning or to signify: "To present oneself as signifying is to speak. This presence affirmed in the presence of the image as the focus of the gaze that is fixed on you, is said" [3, p.66]. According to Levinas, what is expressed is also united with what speaks, the speech of the other is always presented in the form of imperative. Levinas introduces the idea of language as an event of the immediate relation with the other. This language is different from the objectifying language of things and the world; it gives access to the other: "the relationship of language implies transcendence, radical separation, the strangeness of

${ }^{1}$ Richard A. Cohen has elaborated on ethical exegesis in his book Levinasian Meditation. Ethics, Philosophy and Religion [2, p. 94-106]. His discusses ethical exegesis in the context of philosophical dialogue, ethics of commentary and engagement of the reader. 
the interlocutors, the revelation of the other to me" [3, p.73]. It is only in responding to the other that language is born as an intersubjective system. To put it differently, objectifying language becomes posterior and is subordinated to ethical language that is primordially described as an encounter with the other. As Levinas states, "discourse is thus the experience of something absolutely foreign, a pure "knowledge" or "experience", a traumatism of astonishment" [3, p. 73].

It seems to be insufficient to explain language as a ground for dialogue and for the transformation of an individual. Language is the saying in relation to the other and for the other, preceding thematization in which different qualities of the phenomenon are gathered to a sort of unity [1, p. 37-38]. Levinas suggests that "the poem is situated at the moment of pure touching, pure contact, grasping, squeezing - which is perhaps a way of giving, right up to and including the hand that gives. A language of proximity...older than the truth of being...by its for-the-other, the whole marvel of giving" [4, p.41]. The saying is a possibility to approach the infinite; it is a liberation from my own subjectivity. In the saying, I can offer myself to the other and find my being as a being-for-the-other. This offering is a space where responsibility is supposed to be born. In Heidegger's interpretation language articulates itself, and the concept of language does not place subjectivity in question within the appearance and appeal of the other [1, p.47].

Critchley points out that one significant achievement of Levinas' work Otherwise than Being or beyond the Essence is the structure of the saying and the said, that is, how the ethical could signify within an ontological language [5, p.164] The saying is a pure sensibility and openness towards the other; it is affectivity, and it is my inability to refuse the other's approach [1, p. 48-49]. It is thought of as a performative stating or expressive that describes myself facing the other. The said is disclosed as a judgment about which the truth or falsity can be ascertained. Critchley specifies that Levinas' whole project unfolds around one question: how can the saying, my exposure to the other, be said or described in philosophical exposition without finally betraying this saying?

The saying is not the permanent Husserlian epoché of the said; rather, the reduction in the exposure of the saying by way of a continual contestation of the said. The task is to pass beneath or beyond the said to that dimension of experience which transcends the realm of the said towards the other person in its infinite unspeakability. Then, the reduction should take place within the said by interrupting it. Critchley notices that reduction could never be complete: it uses the language of the said and, at the same time, it tries to avoid it. The crucial moment of this process is that this reduced said contains a residue of the unsaid said within the saying: "[the] saying has to be reached in its existence antecedent to the said, or else he said has to be reduced to it" [1, p.46]. Thus, the philosophical discourse moves in a spiral way between two orders of discourse: between the saying and the said, whereby the ethical signifies or shines through the alternation of these orders.

This thesis can also be illustrated by the quote where Levinas addresses Plato: "Plato maintains the difference between the objective order of truth, that which doubtlessly is established in writings, impersonally, and reason in a living being, "a living and animated discourse," a discourse thus "capable of" defending itself, and which knows those to whom it should be addressed and before whom it should be silent" (Phaedrus, 276a). This discourse is therefore not the unfolding of prefabricated internal logic, but the constitution of truth in a struggle between thinkers, with all the risks of freedom. The relationship of language implies the transcendence, the radical separation, the strangeness of interlocutors, 
the revelation of the other to me. In other words, language is spoken where a community between the terms of the relationship is wanting, where a common plane is wanting or is yet to be constituted. It takes place in this transcendence" [3, p. 73].

However, the question remains: how to maintain the transcendence in relation with language? I believe that one of the promising solutions Levinas gradually develops is the notion of exegesis that also leads him to focus on the ethical of exegetic practice. At first glance, a very common reading of exegesis explains it as a response to the text. In the theological context, the term 'exegesis' stands together with 'hermeneutics', however, is both an interpretation of the biblical script, exegesis is applied the practice of interpretation while hermeneutics works with an articulation of concrete rules of interpretation. For Levinas, the ethical exegesis is not just a notion he refers to in Totality and Infinity but also a method that expresses and aims at the 'saying' of the 'said'. In other words, it deepens ethical conditions, whether they are explicitly acknowledged or not, of the text and speech. The notion of ethical exegesis was also emphasized and elaborated by Richard A. Cohen in his outstanding book Levinasian Meditations. Following Levinas's path of reading, he articulated four interrelated dimensions of ethical exegesis among which "pluralism of persons and readings" and "virtue, or existential self-transformative wisdom" are of special interest in the current discussion [2, p. 94].

The existential self-transformative path, revealed in the practice of ethical exegesis, is bound, according to Cohen's interpretation, to "relevant hermeneutics". This is a movement of sympathetic entering into texts together with an inner understanding that applies to the vivacity of life and the sensibility of experience and not only to the intellectual engagement of the reader. The dominating critical attitude in reading often lacks this sympathetic sensibility and sacrifices it to the objectivity of knowledge and the purity of the methodology of reading. Alternatively, exegesis is about showing how the ethical signifies within an ontological language. To put it differently, exegesis is also a model of the saying and he said that explains an experience of being transformed by the text and within which the reader can unfold its sensible self: "Exegesis made the text speak; while critical philosophy speaks of the text. The one takes the text to be a source of teaching, the other treats it as a thing" [6, p. 263]. Broadly stated, the ethical exegesis does not neglect a critical approach to the text but tends to emphasize the teaching wrapped in texts. In this compact sentence, Richard Cohen finds a residue of an absolute transcendence of dialogue. And this is exactly what Levinas's objective is to establish proximity of two speakers who remain separate yet united and who are able of retaining their individuality. Thus, the ethical exegesis would be a move that forms relations within the text and where "the transcendence is proper to the discourse from out of which the relative transcendence of true knowledge is discovered" [2, p. 103].

In a more detailed exposition, the ethical exegesis aims to preserve the saying of the said and to create the ethical conditions for the search of truth. These ethical conditions address first of all sensible embodied person to whom, following Levinas's line of reflection, the Western philosophical tradition was blind. "Truth arises where a being separated from the other is not engulfed in him, but speaks to him. Language, which does not touch the other, even tangentially, reaches the other by calling upon him or by commanding him or by obeying him, with all the straightforwardness of these relations" [3, p. 62]. Now, coming back to mentioned Levinas's quote referring to Plato's Phaedrus. In the history of philosophy, Plato's dialogues stand as a wonderful example of how exegesis works. Levinas 
believes that the skills, the art, and spirit Plato employs in his dialogues, preserve the unity in difference and a relation of a non-indifference of one person to another, or, in other words, preserve responsibility of one interlocutor for the other.

Thus, ethical exegesis turns to be not only a praxis of interpreting but also an interaction of encounters and their inspiring ideas, utopias and it is also the proximity of embodied individuals expressed in the interplay of the saying and the said. The way Levinas approaches Plato's text is that Plato adopts a similar strategy to the one used in the interpretation of Talmud. Cohen notices that a distinctive feature of Plato's is not the dialogical form itself but our commentary which is activated and is living at the very moment when we are engaging ourselves, "when we 'take it to heart', because are able of distancing of academic jargon" [2, p. 105]. In Totality and Infinity Levinas writes: "it belongs to the very essence of language, which consists in continually undoing its phrase by the forward or the exegesis, in unsaying the said, in attempting to restate without ceremonies what has already been ill understood in the inevitable ceremonial in which the said delights" [3, p.30].

In the first moment of reading, the textual voice or surface seeks for an embodied person. The intriguing answer Cohen gives in Levinasian Meditations is that "no interlocutor too important to be challenged or too insignificant to be ignored, because it is a text driven by a moral desire, or more precisely, by a holy compassion for others, to alleviate the suffering of others, and to in this way come close to God, to bring God's will to earth and to raise human will to God" [2, p. 104].

One of the further possible ways of exploring this theme would be to address Critchley's account of language. In The Ethics of Deconstruction Critchley proposes 'clôtural' reading as a critical step towards the history of philosophy. 'Clôtural reading' comprises a double structure involved in reading the text. Critchley explains it as follows: to preserve the question of ethics, the text is analyzed "in terms of how it is divided against itself in both belonging to logocentric conceptuality and achieving the breakthrough beyond that conceptuality" $[5, \mathrm{p} .30]$. The interesting point Critchley is making is that conceptual insight of the 'clôtural reading' is grounded on deconstructive reading. On the one side, 'clotural reading' is adjusted to a logocentric epoch that is closed and on the other side, as Critchley explains it, it also requires a deconstructive reading which is constantly disturbing this closure and is disrupting the flow of the philosophical discourse in order to allow the appearance of alterity. This incoming movement of alterity interrupts "any unity of logocentric textuality and epochality" [5, p.30]. Thus, the notion of 'clôtural reading' opens up a possibility of questioning the ethics, but also it stands close to what Levinas articulates as the ethical exegesis. It is clear that Critchley also views 'clôtural' reading to be a method of reading the history of philosophy seen from the standpoint of the others, of alterity, of embodied interlocutors, and of the victims of that history; the idea of 'clôtural' reading is to speak out the ethical history which corresponds to the practice of ethical exegesis. Critchley writes that "clôtural' reading articulates the ethical interruption of ontological closure, thereby disrupting the text's claim to comprehensive unity and self- understanding" [5, p.30]. The purpose of this reading as well as of ethical exegesis is to reveal a diversity of insights, interruptions, or alterities hidden in the text and which are the moments of ethical transcendence. In this way, within the practice of reading the language of ethics would be an event where the saying shines through the ontological exposition of the said. 
John Llewelyn provides another inspiring reading of exegesis in Levinas's ethics. To perform ethical exegesis is to hear and to listen (écouter, entendre). Listening is not just an active engagement but, to some extent, a traumatic passivity where the embodied self is turned out and is forced to obey. Llewelyn goes on to articulate that the trope "by which the inner ear turns to Autrui, is the turning of my skin inside out, it is the turning of the ego into itself, a self whose responding to the other is its obedience, an obedience prior to the knowledge of what it is commanded" [7, p. 184]. Llewelyn adopts a similar argument with respect to Levinas's idea of exegesis, however, he radicalizes it by articulating inescapability of response and obedience. These are the tropes found in exegetic practice and 'clôtural' reading, and they are already before any layer of information comes into play. Llewelyn's understanding of the concept of language and interpretation in Levinas's ethics are also challenging. He points an important moment that the discourse of communication is the one-way communication of the self to the other where the performed saying is not the saying of the said of the message. Moreover, if to express it in French, the saying is se dire, and ' $s e$ ' indicates an accusative form of the self; the accused me and my saying signifies a gesture of giving of myself to the other. In Llewelyn's terms, it is a radicalization of ethical exegesis, but the opening up initiated by the exegetical method leads to being disquieted by the other [7, p. 184].

On the first opening page of Otherwise than Being of Beyond the Essence Levinas quotes Rachi, the medieval commentator of the Talmud: "The sages have said, Do not read 'begin at my sanctuary', but 'begin with those that sanctify me' $<\ldots>$ as teaches the Talmudic Treatise, Sabbath, 55a" (Ezekiel 9: 6). The reason why Levinas refers to Rachi is to show, in an indirect way, that the whole text of Otherwise than Being is formed as an exegetical response, an attempt to maintain silence and responsibility in writing for. I suggest that already this short passage points to the practice of ethical.

Before I move to the idea of the ethical body there is still one more important point to add to the discussion. Involving interlocutors of flesh and blood, in all the vivacity of their life, ethical exegesis also concerns sensibility, sensation, and proximity which in their turn condition ethical body. The speaker, or the other delivering a message, is unreachable for thematizing consciousness. However, Levinas affirms it can be accessible in proximity [1, p. 88]. He discloses verbal discourse not only as an additional component to the knowledge that can be recognized. Verbal discourse arises from the proximity preceding the pronunciation, that is, he reserves a privileged place for non-verbal communication. In Totality and Infinity Levinas writes that "the eyes break through the mask — the language of the eyes, impossible to dissemble. The eye does not shine; it speaks" [3, p.66]. Most appropriately, the ethical relation to the other interlocutor should not be brought back only to speech, but it can signify ethically by non-verbal indicative signs. However, the notion of proximity as non-verbal communication differs from the perception of the visual. Let us remind ourselves of Husserl's account of sensible intuition which is actually based on the perception of a visual image; it is the primacy of vision upon senses. In Levinas's view, the real meaning of sensation is hidden not in the process of receiving information which happens as a result of our proximity to objects. If sensation is read as a fulfillment of intention, then this understanding of intention is totally wrong since the real intuition can never be accomplished; it is unsatisfied. Also, Levinas points out that a particular feature of sensation is that it happens. It is a meaningful event which happens between the feeling and the felt. Not only was the notion of sensation transformed in our contemporary 
culture. Touch was also reconsidered as a way of receiving information. Touch in Levinas's phenomenology is a certain concentration of knowledge on the surface of an object. This means that a new notion which can reflect and conceptualize the idea of feeling (visual and tactile) is needed, and it partly explains Levinas's invention of proximity. The notion of proximity reconsiders the visual and tactile sensation; they are no more subjected to language as the said.

Why does Levinas accentuate the notion of proximity and sensibility within the ethical explanation of language structure? Proximity, as a mode of describing the saying, does not presuppose a spatial location. Levinas writes: "Proximity is a relationship with a singularity, without the mediation of any principle or ideality. In the concrete, it describes my relationship with the neighbor, a relationship whose signifyingness is prior to the celebrated 'sense bestowing" [1, p. 100]. Proximity becomes a newborn intentionality for Levinas. In other words, I cannot escape proximity to the Other, since before I cognize something, I discover myself being appealed by the Other; proximity is a structural component of consciousness. In fact, such an approach to the other excludes any thematization or possession. The singularity of this ethical proximity excludes mediation through universal notions that belong to language. Language is thought to be an 'inter' space that indicates the appeal of the Other. Levinas underlines this statement in a very poetical way: "the precise point at which this mutation of the intentional into the ethical occurs, and occurs continually, as the approach breaks through consciousness, is the human skin and face. Contact is tenderness and responsibility" [8, p. 116]. This special foundation of language is caused by Levinas's desire to free language from logical discourse. So long as thought is the functional model governing any uses of language, it must remain embedded in the ideality it acquires from the basic intentional structure. It is for this reason that Levinas discusses the nature of the sensible in terms of intuition and the metaphysical desire. The sensible, according to Levinas, can be the only approach to the other and it cannot be known. The sensible does not offer to consciousness something which may not be integrated into the structure of the world $[9, \mathrm{p} .36]$. It establishes unique access to the truth. The original proximity whereby the self is related to the Other is achieved in non-verbal sensibility. "The relation of proximity $<\ldots\rangle$ is the original language, language without words or propositions, pure communication" [8, p. 119]. Language is originally a wordless approach and tactile contact. To formulate it differently, it is nudity of skin and silence.

To sum up this part, I would like to stress that Levinas's project of ethical exegesis is to re-trace the passage to transcendence, where commentary, reading, and dialogue would be aiming at the ethical saying within the said of the philosophical discourse. The ethical exegesis is not purely a practice of a contemplative mind but rather an articulation of sensible embodied self, manifesting in the proximity of two interlocutors. My main claim is that ethical exegesis does not stand alone but is tightly bounded to the ethical body found at the core of subjectivity.

\section{Ethical body and sensibility}

My guiding line in examining ethical body is the title of Levinas's second major book Otherwise than Being or Beyond the Essence. Here I specifically draw attention to the statement 'otherwise than being. Mention of 'otherwise' might provide the clue to Levinas's 
answer why one should bring into discussion embodied subjectivity. During the entire history of Western thought the body was understood in terms of being, but for Levinas, the meaning of human embodiment is revealed 'otherwise than being. He claims that at the very origin of being for the other person there is already embodied ethical expression. In the same spirit, in Levinasian Meditation Richard Cohen writes that each moral action and ethical becoming exceed being [2, p. 37]. And obviously, the human body is the moral body which goes beyond conceptualization of being. The development of our civilization was always based on our capacity to provide preservation of life and the self and of the body in the first place. One could see that there is indeed a certain ambiguity within different modalities embodied subjectivity: it is not just self-providing and satisfaction of needs of life, but in doing this one goes beyond animality and eventually is building up the ethical realm of the human.

In its origin our embodiment is enjoyment, a satisfaction of needs, it is aging and suffering, it is exposure and vulnerability. And therefore, only the vulnerable, mortal, embodied being is capable of encountering an ethical demand: "a shudder of incarnation though which giving takes on meaning, as the primordial dative of the for another, in which a subject becomes a heart, a sensibility, and hands that give" [6, p.182].

Thus, Levinas proposes a kind of reverse reading of any theoretical discourse. He believes that the starting point for the philosophy is not a divergence of mind, mental constructions together with embodied being; the history of philosophy and the science should be understood as theory and practice grounded in a concrete situation, incarnated in language and time, expressed in varieties of embodied subjectivity. This attitude was not totally ignored in the history of Western thought. Levinas mentions that there are two traditions intertwined which could shed light on the concept of ethical embodiment. During Ancient time, and here Levinas mostly refers to Parmenides, being and time are thought within the realm of rationality, and where the body occupies a lower level and is often "sacrificed to eternity" [2, p. 38]. Another period comes with Bergson, where being and time are finally thematised in terms of existence. That was an important breakthrough, which assigned the body the first place. In his commentary on Levinas's view of the embodiment, Cohen describes two promising lines of contemporary thinking. The first one, represented by Bergson and Heidegger, is revealing the body as an aesthetic body. Another one, and here one could also refer to Merleau-Ponty, is conceiving body as the ethical body.

Levinas indeed develops a concept of ethical embodiment in a very detailed way. As I discussed in the previous part the ethical essence of language, from which the experience of obligation derives, originates in the sensibility of the skin of the other's face and in proximity. The meaningful relation to the other is maintained by a non-verbal language of skin. The ethical self is an embodied being of flesh and blood, a being who is capable of hunger, who eats and enjoys eating - "only a being that eats can be for the Other" [1, p.74]. Even though we are always tending to build up our existence on rational consideration, we are ridden with all possible inclinations and aversions, desires for pleasure, fame, prestige, power, and love which format our sensibility. This sensibility is not only a desire for happiness, it is neither manifestation of pure rationality nor pure materiality. Describing ethical body Levinas insists on the priority of moral responsibility specified in terms of temporalizing unfolding body. Here, I will not touch upon a discussion of the temporality of the body, however, I would mention that contrary to Bergson or Heidegger 
Levinas sees embodiment as unfolding temporal flow, as mortality and as historicity with an imprint of alterity and as being marked by the humanity of the other person. Levinas articulates that "corporeity describes the ontological regime of a primary self-alienation" [3, p. 226]. The body is at the same time my body, my concrete embodiment and a thing in the world with and for others. He writes: "The body exceeds the categories of a thing, but does not coincide with the role of "lived body" ("corps propre") which I dispose of in my voluntary action and by which I can. The ambiguity of corporeal resistance which turns into a means and from means turns into a resistance does not account for its ontological hybrid. The body in its very activity, in its for itself, inverts into a thing to be treated as a thing" [3, p.229]. Here the accent is on the embodiment emerging as mortality but also as justice. This is a phenomenological description of the self-presence that reveals how the self is built and what are the components of the embodied self which are needed in order to be faced by or to accept the call from the other person.

In a very short manner, I will further address these components of embodied sensibility, namely Levinasian description of the formation of the ethical body including enjoyment and hunger. Being not the easiest concept to read, enjoyment stands as a starting step towards unfolding ethical embodiment. To support this claim, I address one of the famous citations from Totality and Infinity: "The I is thus at home with itself. Through the home, our relation with space as distance and extension is substituted for the simple "bathing in the element". But the adequate relation with the element is precisely bathing. The interiority of immersion is not convertible into exteriority. $\langle\ldots\rangle$ To bathe in the element is to be in an inside-out world" [3, p. 132]. This "bathing in the element" of life itself is also an affective experience of being at home ("chez soi") and where dwelling manifests as the enjoyment of materiality of the world and of mastering it.

Enjoyment described as "bathing in the elemental" is a pure sensibility, which is not originating from the first position of the I. The ego is contested by affection or, in other words, is melted in enjoyment without intending any purpose. In his analysis of enjoyment and affective state of sensibility Levinas focuses a great deal of attention on the "contraction" of a sentiment which subjectivity is experiencing. An important claim here is that the I does not generate enjoyment and therefore is not taken as a source of enjoyment. Rather in this surprising state of enjoyment subjectivity does not have any chance to return to the sameness of the self in satisfaction of its need. The being of the subjectivity is constructed not only on the experience of enjoyment or the enjoyment of enjoyment but the I also builds its existence on enjoyment. Building existence on enjoyment means that the subject originates from affective experience of life.

Bathing in the materiality of the world embodied subjectivity arises from self-sensing of sensibility, which is gradually designed for enjoyment. The enjoyment is also related to being hungry. Levinas writes that "only a subject that eats can be for-the-other" [1, p. 74]. In its hunger and a constant search for satisfaction, subjectivity is for the first time disclosed to be vulnerable. And, together with hunger comes to pain that, to some extent, forces subjectivity to stay in modality for-itself. The sensation of hunger is truly mine, even though the sensation may not be fully recognized by me. It sketches and sharpens the existence of subjectivity as a localized body.

The hunger, but also tasting, is my embodiment where getting "food", choosing what I eat, is the identification of what is me. In Otherwise than Being or Beyond the Essence Levinas states: "The taste is the way a sensible subject becomes a volume or the irreducible 
event in which the spatial phenomenon of biting becomes the identification called me, in which it becomes me through the life that lives from its very life in a frueri vivendi" [1, p.73]. The subjectivity creates its own volume or, in other words, a sense of the self, from the taste of what it enjoys.

Describing the emergence of the ethical body in hunger and enjoyment Levinas gradually intends to resituate a relation to transcendence. This project comprises two aspects of embodied sensibility: the sensibility of enjoyment before the ethical encounter and the sensibility in a face-to-face encounter. It is important to note that in these two cases of sensibility, the sense bestowal comes from outside and structure of enjoyment reverses intentionality in such way that it does not have noesis-noema correlation. This modality of sensibility grasped in enjoyment is prior to any construction of meaning and, according to Levinas, provides access to transcendence. The transcendental character of sensibility is eventually determined by the moment of the contact with the other. The profound nuance, which Levinas wants to point out, is that the contact itself should not be read as a consciousness of contact but rather subjectivity is subordinated to that with which it is in contact. As Levinas puts it, "[ $t]$ his situation is not reducible to representation, not even an articulate representation; it belongs to sensibility, which is the mode of enjoyment. It is when sensibility is interpreted as representation and mutilated thought that the finitude of our thought has to be invoked so as to account for these "obscure" thoughts. The sensibility we are describing starting with an enjoyment of the element does not belong to the order of thought but to that of sentiment, that is, the affectivity wherein the egoism of the I pulsates" [3, p. 135].

In relation to the above, it is worth pointing out that the formation of the ethical body is an originative component of ethical exegesis: within the confines of exegetical practice, one finds sensibility expressed in the ethical embodiment. Perhaps only the promise of responsibility born together with ethical body silently speaks within philosophical tradition. Ethical embodiment turns into a particular mode of poetic being, it is productivity and creativity, but also in being creative one is exposed to all dangers and violence. To be embodied is to be wounded with an essentially ambiguous existence: one is for oneself and also eventually for others. Considering the body and will, we enter into the public sphere. From the first enjoyment but also from being hungry, one is exposed to others without one's voluntary will. The subjectivity finds itself already bounded to others and to all these spheres of embodied existence, which mark the human realm as opposed to a purely natural dimension of being. Therefore, as Levinas makes clear, one has to start with embodiment revealed as the ethical one: "responsibility for another is not an accident that happens to a subject, but precedes essence in it, has not awaited freedom in which a commitment to another would have been made. I have not done anything and I have always been under accusation - persecuted" [1, p. 114].

As a final mark, I should add that in the context of Levinas's ethics the idea of the 'end of philosophy' is often employed to mean the transition from philosophical theory to ethics. This means to address the subject of flesh and blood who cannot escape an intersubjective signification, i.e. cannot escape 'interhumanity'. As Levinas elegantly puts it: "The self is a sub-jectum; it is under the weight of the universe, responsible for everything" [1, p. 116]. The reason why Levinas talks about the end of the philosophy is that the whole discourse of the Western philosophy was mostly developed as the said ignoring alterity and the other. Henceforth he denotes basic philosophical inquiry and moves to 'ethics as first philosophy' This is indeed simple but yet different ethics: to perform unsaying of the 
said by the outlining importance of the approach to the other interlocutor that is articulated as ethical exegesis and originated in ethical body and sensibility.

\section{References}

1. Levinas E. Otherwise than Being or Beyond Essence, trans. Alphonso Lingis. Pittsburgh, Duquesne University Press, 2006. 205 p.

2. Cohen A. R. Levinasian Meditations. Ethics, Philosophy, and Religion. Pittsburgh, Duquesne University Press, 2010. $380 \mathrm{p}$.

3. Levinas E. Totality and Infinity: An Essay on Exteriority, trans. Alphonso Lingis. Pittsburgh, Duquesne University Press, 2004. 314 p.

4. Levinas E. Proper Name, trans. Michael B. Smith, Stanford, Stanford University Press, 1976. xii + 191 p.

5. Critchley S. The Ethics of Deconstruction. Derrida and Levinas. West Lafayette, Purdue University Press, 1999. $x v+293 p$.

6. Levinas E. Levinas Reader, ed. Sean Hand. Oxford, Basil Blackwell, 1989. 311 p.

7. Llewelyn J. Emmanuel Levinas. The Genealogy of Ethics. London, New York, Routledge, 1995. 256 p. $194 \mathrm{p}$

8. Levinas E. Collected Philosophical Papers, trans. Alphonso Lingis. The Hague, Martinus Nijhoff, 1987.

9. Levinas E. Basic Philosophical Writings, eds. Adrian Peperzak, Simon Critchley, and Robert Bernasconi. Bloomington, Indiana University Press, 1996. 201 p.

Received: 19.02 .2018

Accepted: 10.05.2018

Author's information:

Irina Poleshchuk - PhD in Social Sciences, Associate Professor; irina.poleshchuk@ehu.lt, ira_pole@fastmail.fm

\section{Этический экзегезис и этическое тело в философии Э. Левинаса}

\section{Полешук Ирина}

Европейский Гуманитарный Университет,

Литва, 01114, Вильнюс, ул. Тауро, 12

Для цитирования: Poleshchuk I. Ethical exegesis and ethical body in the philosophy of E. Levinas // Вестник Санкт-Петербургского университета. Философия и конфликтология. 2018. Т. 34. Вып. 3. С. 356-368. https://doi.org/10.21638/11701/spbu17.2018.304

Цель статьи - показать, что тезис Левинаса «этика как первая философия» предполагает радикально иной подход к философскому дискурсу и языку. Анализируя позицию Левинаса, автор демонстрирует, каким образом пересматривается паттерн прочтения и дискутирования, традиционно присущий западному философскому мышлению. Это предполагает определенные концептуальные шаги, описанные как этический экзегезис и этическое тело. Этический экзегезис представляет собой практику «слушать другого» и «быть для другого собеседника», которая направлена прежде всего на воплощенного субъекта во всех проявлениях его жизненного мира. Чтобы продемонстрировать принцип работы экзегезиса в модальностях чувствительности и воплощенной близости, в рамках феноменологической традиции автор рассматривает концепцию языка в философии Левинаса, а именно говорение и сказанное. Таким образом, основной тезис статьи состоит в следующем: Левинас не только пересматривает функционирование языка в философском дискурсе, но и открывает новые подходы к диалогу, способам участия и слушанию. Иными словами, объективирующий язык оказывается подчинен- 
ным этическому экзегезису, который описан Левинасом как встреча с воплощенным другим. Именно поэтому особое внимание уделяется рассмотрению структур чувствительности (наслаждение и голод) и близости, которые являются необходимыми компонентами, формирующими этическое тело. В статье поясняется также, что постоянное уточнение Левинасом концепции экзегезиса в различных его работах направлено на возвращение и приближение к трансценденции.

Ключевые слова: Левинас, этика, экзегезис, воплощение, близость, чувствительность, этическое тело, язык, говорение, сказанное.

Контактная информация:

Полемук Ирина — PhD in Social Sciences, доцент; irina.poleshchuk@ehu.lt, ira_pole@fastmail.fm 